\title{
Sense and Limits of the Fichtean Project of a Closed Commercial State
}

\author{
Héctor Oscar Arrese Igor \\ Centro de Investigaciones Filosóficas, \\ Consejo Nacional de Investigaciones Científicas y Técnicas, \\ Argentina \\ harreseigor@gmail.com
}

\begin{abstract}
In this paper, I intend to determine the objectives and limitations of the project developed by Fichte in The Closed Commercial State. In order to achieve these aims, I first identify the problems that are left open in the cosmopolitan right of the Foundations of the Natural Right, in particular by virtue of the assumption of universal egoism. In this way, I seek to understand the project of The Closed Commercial State as an attempt to solve these outstanding issues. Thereafter, I reconstruct the central argumentations of the later text in order to make its architecture clear, according to its primary objectives. Finally, I consider the problem of the viability of this project, taking into account the lack of a moral education for the citizens focused on certain moral and psychological dispositions, which should reduce the greed for superfluous goods.

Keywords: state, commerce, Fichte, right, economy, property, justice.
\end{abstract}

Received: 22 - 07 - 2016. Accepted: 08 - 12 - 2016.

DOI: http://dx.doi.org/10.21555/top.v0i54.828

Tópicos, Revista de Filosofía 54 (2018), 215-236. 


\title{
SENTIDO Y LÍMITES DEL PROYECTO FICHTEANO DE UN ESTADO COMERCIAL CERRADO
}

\author{
Héctor Oscar Arrese Igor \\ Centro de Investigaciones Filosóficas, \\ Consejo Nacional de Investigaciones Científicas y Técnicas, \\ Argentina \\ harreseigor@gmail.com
}

\begin{abstract}
Resumen
En este trabajo busco determinar los objetivos y limitaciones del proyecto desarrollado por Fichte en El Estado comercial cerrado. Para alcanzar dichos objetivos, en primer lugar identifico los problemas que son dejados abiertos en el derecho cosmopolita en el Fundamento del derecho natural, en particular en virtud del supuesto del egoísmo universal. De este modo, procuro comprender el proyecto de El Estado comercial cerrado como un intento de resolver estos problemas pendientes. Luego apunto a reconstruir los argumentos centrales del último texto, a fin de echar luz sobre su arquitectura, de acuerdo con sus objetivos primordiales. Finalmente, considero el problema de la viabilidad de este proyecto, tomando en cuenta la falta de una educación moral de los ciudadanos en torno de ciertas disposiciones morales y psicológicas, que deberían reducir la codicia por bienes superfluos.

Palabras clave: estado, comercio, Fichte, derecho, economía, propiedad, justicia.
\end{abstract}

Recibido: 22 - 07 - 2016. Aceptado: 08 - 12 - 2016.

DOI: http://dx.doi.org/10.21555/top.v0i54.828

Tópicos, Revista de Filosofía 54 (2018) 
The Closed Commercial State is an indispensable work to comprehend Fichte's political thought including the problem of the international right. But it is also a fundamental text because of its historical impact and its several receptions over the course of more than two centuries.

Christian Gottfried Körner among others can be mentioned, who in a letter to Schiller dated $29^{\text {th }}$ December 1800 wrote that The Closed Commercial State has tried to conduct "political witchcraft" (politische Ketzerei), which only Robespierre would have dared to carry through in his "system of terror" (Schreckenssystem); this would transform Fichte into a "philosophical Attila". Samuel Taylor Coleridge, in the same sense, wrote in the back cover of his exemplar of the text that "Fichte would have been a much more pernicious and despicable tyrant than Caligula or Elagabalus" (Nakhimovsky, 2011: 4). On the other hand, Adam Müller criticized the Fichtean project inasmuch as it closes the state to the external commerce and, as a result, left it lagging with respect to the economical and technological progress of the rest of mankind (Marquardt, 1991: 299-300).

Karl Grünberg placed Fichte among the socialists, since he would defend a social, economic, and legal order based upon the collective property and opposed to the private property. Despite the fact that this interpretation does not follow the Fichtean text, Eduard Zeller's statement that Fichte would have been the first thinker who posed the social problem in Germany is interesting (Lindau, 1900: 59-60).

In the same interpretive line, the relationships that Marianne Weber established between the Fichtean and the Marxist theory are suggestive. In particular, Weber correlated the Fichtean thesis that everyone has the right to an enjoyable life with the Marxist idea of a universal right to have access to natural goods as a result of their own effort. She also showed the coincidence of both projects in the idea that the human being can elevate above the animal kingdom inasmuch as he or she stops exploiting other human beings for a living (Weber, 1900: 114).

On the contrary, the conservatives resumed the social division of labour in guilds (Zünfte) as an alternative to the Marxist class struggle as well as the market liberalism. The nationalist economists in general gave to The Commercial State a conservative profile (Merle, 2006: 401). Among the wide variety of interpretations that the Fichtean text has received, there are some people who have seen it as a militarist economy that is thought for wartime. Others share the interpretation of the Prussian censor who, towards 1822, declared that this text should 
not be published because of its republican and extremely subversive character. Besides, Ferdinand Lasalle considered that this project was a forerunner of the future German Republic, John Dewey saw it as a precursor of the Welfare State, and Samuel Flieschbaker suggested that it was a predecessor of the contemporary idea of the distributive justice (Nakhimovsky, 2011: 5-6).

In spite of this kaleidoscope of readings and appropriations, in this paper I do not try to put them into consideration, but rather I seek to test the consistency of the text, above all with respect to the problems posed three years before its publication, on the occasion of the natural right of Jena. For this reason, I will first focus on the Fichtean strategy to regulate the relationships between the states, which is thought of as an appendix of his Foundations of Natural Right. In particular, I will take into account the role that the assumption of the universal egoism plays in order to give consistency to the project. Then, I will show the problems that are left open by the natural right of Jena in order to analyse the treatment they receive in The Closed Commercial State. Finally, I will examine the viability of the theory developed in this last text.

\section{The cosmopolitan right in the Foundations of the Natural Right}

Political concerns have remained constant in Fichtean thought. Since his revolutionary writings of his early times, Fichte dealt with problems such as the fundamental right of citizenship, the role of the state, the relationships between the citizens and the government, etc. But in his Foundations of Natural Right, he systematizes his reflections in a more articulated way, laying the basis for what would be his most mature thought.

In his Foundations of Natural Right, Fichte deals with the cosmopolitan right once he has completed the design of his ideal of a just state. The Fichtean political community is organized around the government, who concentrates the three powers in his hands in order to guarantee the right to existence for all. This conception of the exercise of government is based upon the universal egoism, which is assumed to give stability to the political community in case the worst of all possible scenarios takes place. The adequate mechanism to this scenario is what Fichte calls "the right to coercion", which implies the fulfilling of the law out of fear of 
losing the freedom and property. In this way, each one's egoism results in the guarantee of the common good.

The right to existence, insofar as it is the ultimate end of the state, assumes in turn the right to property, understood as a sphere of possible actions. For this reason, the state must plan the economy in a centralized way for the purpose of avoiding the possibility that the fundamental right ends up being subordinated to the anarchy and the hazard of the free market.

Nevertheless, the state cannot avoid the possibility that its citizens come into contact with the citizens of other states for many reasons. Therefore, Fichte decides to introduce the problem of the cosmopolitan right. Using the same methodological tool of his theory of the state, Fichte imagines the worst of all possible scenarios and concludes that each citizen will have the right to ask the other to submit to the coercion of his or her own state in order not to risk his rights (Fichte, 1796/1797: 369). Nevertheless, this requirement is impossible to fulfill given that it would anihilate itself and given that no one will have the obligation of submitting to the legislation that rules the other's state.

Consequently, Fichte foresees that, in the case that the citizen of the own state attacks the property or freedom of a foreigner citizen, he or she must be judged by our state in the same way that it would have been judged by our state if he had attacked a fellow countryman (Fichte, 1796/1797: 370-371). Obviously, the official responsible must act according to the criterion of reciprocity, which means that the own state must take care of the citizens of the other state, insofar as the other behaves correspondingly (Fichte, 1796/179: 371). In the case that the own state cannot recognize certain legality in the other, it is legitimated to declare war on the other (Fichte, 1796/1797: 372-373).

In other words, if the other state is not trustworthy, it represents a danger for the sovereignty of the others, and because of this reason, it loses all of his rights in front of the others, who are legitimated in turn to submit it limitlessly (Fichte, 1796/1797: 377). Hence it follows that the threat of the war declaration operates analogously to the right to coercion inside the political community, insofar as the submission would take away from the state all sovereignty and self-determination.

Nevertheless, that leads us to another problem, which consists in the way this threat of war could be made believable, so that it has a real dissuasive effect. For this to happen, the states that sign the interstate agreement of mutual protection must be able to unify their forces for 
the purpose of creating force that must be superior to each one taken individually (Fichte, 1796/1797: 379).

On the other hand, this task implies another challenge given that this resultant force cannot be monopolized by an universal state (Völkerstaat), which subjects the other states, insofar as these communities would lose their sovereignty and as a result the possibility of guaranteeing the rights of their citizens. Therefore, it must be a federation of states (Völkerbund), where each one can integrate into it voluntarily from a sovereign decision. This implies that the states can establish relationships between them even out of this federation (Fichte, 1796/1797: 379-380). The structure of this federation must consist of an international court, which would evaluate the eventual declaration of a war against those states that do not respect the legality of the others.

However, I think that the Fichtean project is not able to annihilate the asymmetries of power between the states, because there is not an ultimate instance of power that can monopolize the use of the power. This instance is indispensable because the assumption of the universal egoism prevents thinking of an organization inside in which each state could participate in debates and take part in important decisions. The reason for that is that the states, left to their own free decisions, would disintegrate in a fierce fight for power over the others.

In this context, those states which have the strongest economic and military power could influence over the decisions of the court, given that there is no neutral instance that could prevent them for doing so. In other words, this organization would depend on a precarious balance of power between the states. However, this seems more to be an anarchic community than the concept of right defended by Fichte.

Coming back to the main objective of the Fichtean State, this scheme of international relationships does not guarantee the self-determination and sovereignty inside each state but rather leaves them at the mercy of the swinging relationships of power. As a result, the rights of property and freedom as well as the basic right to self-preservation do not remain protected, and the entire Fichtean project is something difficult to realize.

As a consequence, I think that the assumption of the universal egoism puts in danger the consistency of the theory. From my viewpoint, the cosmopolitan right poses another problem, because it analyzes the international right from the starting point of the relationships between the individuals of the different states and then takes into account the legal relationships between their states but never focuses on the importance 
of economic and social rights. In particular, this text leaves out of analysis the problem of the asymmetries with respect to the property and the access to the labour market, the relationships of colonialism and commercial imperialism, etc.

These problems were an object of a later text, The Closed Commercial State, published in 1800, which served to bridge the periods of Jena and Berlin. In the following section, I will reconstruct Fichte's efforts to solve the open problems of his theory.

\section{The idea of a distributive justice}

In his work, The Closed Commercial State, which according to his son had been Fichte's most articulately posed text, he tries above all to solve a deep problem for political theory (Nakhimovsky, 2011: 6). It is the question of the elaboration of a political theory, which must be applicable to the particular historical situations but without its principles and categories losing universality. ${ }^{1}$ As Kant had said before, Fichte complains about the politicians asking the philosophers for advice but afterwards not taking it into account, which could have to do with a failure in the construction of their theories (Fichte, 1800: 389-390).

Fichte's diagnosis points out two big causes of this theoretical deficit. On the one hand, some philosophers have elaborated such general theories that there is no way to apply them to any specific context. It is as if someone would have deduced the relationships between the sides and the angles of a triangle without having measured any real side or angle before. This would be a merely ideal theory (Fichte, 1800: 390). On the other hand, empiricist politicians refuse to refer to any abstract concept that could transcend the immediate experience. As a consequence, they only solve current problems by imitating the answers given by others in the past when facing similar situations, renouncing to all forms of originality. Fichte argues against this position that what they do no not take into account is that the politicians whom these theorists imitate in their moment had to give a first creative response to the problems at hand, because no one had faced them before (Fichte, 1800: 391-392). In

1 Fichte, J. G. (1800: 390-391). In spite of Fichte's efforts, Carl August Struensee, in a letter to Karl Friedrich Beyme, the Chief of the Royal Cabinet, communicated him that The Closed Commercial State was an entirely theoretical text. Therefore it was not a book which could be taken seriously as a guide for the state policy (Nakhimovsky, 2011: 128).

Tópicos, Revista de Filosofía 54 (2018) 
summary, the merely empirical conception of politics would lead to an eclecticism without much consistency.

With this methodological desideratum in mind, Fichte designs a theory in three moments. First, he determines the principles of justice within the framework of his theory of the state. In the second place, Fichte tries a diagnosis of the historical conditions of the Europe of that time in order to establish the challenges faced by his project. Finally, he designs a procedure to modify the current situation according to the principles of justice he defends.

Fichte looks for the normative principles of commerce with a criterion as a compass - that is to say that truth lies at a middle point between two false statements that are contradictory to each other (Fichte, 1800: 399). With this criterion at hand, Fichte rejects two conceptions, which he considers so opposed to each other as false at the same time. According to the first, the state would have the tutorial function of leading its citizens towards a happy or self-fulfilled life, a virtuous or eventually a blessed one. Opposed to this purely paternalistic conception of the state, Fichte puts the conception of the state as a mere guarantor of the current relationship of ownership, such as they are actually organized, which he considers a wrong idea. ${ }^{2}$ In the middle point, Fichte finds his own conception, consisting in the reorganization of the relationship of property and having as a criterion the principles given to us by reason (Fichte, 1800: 399).

For the purpose of delving further into the Fichtean research about the principles of justice, it is necessary to clarify the concept of property. This right is a form of activity in the world of the senses. Therefore, Fichte does not define it in terms of the mere exclusive possession of an object (Fichte, 1800: 421).

Meanwhile, the right to property must be regulated because it is unavoidable that conflicts between the citizens will take place, inasmuch as they act on the world of senses and intervene in the other's actions. In this point, Fichte continues the Kantian thesis that the spherical surface of the Earth makes the individuals to come into contact and therefore conflicts rise (Kant, 1795, VI, § 13: 262). As Fichte reasons, one cannot say that he or she has the right to eat the fruits of a tree that only one

2 Both positions rejected by Fichte were given by the state interventionism of Dalberg and Christian Wolff on the one hand and, on the other hand, by von Humboldt's liberalism. See Moggach (2009: 1016).

Tópicos, Revista de Filosofía 54 (2018) 
has access to, since it is impossible to be in conflict with oneself (Fichte, 1800: 400-402).

What happens is that when we act, we inevitably make use of the object that the other needs for his or her own purposes as well. This makes necessary that each one declares which goods or privileges he or she will need and promises not to use those that the other declares as necessary for his or her action (Fichte, 1800: 400-402). Nevertheless, it is necessary to enter into more detail with respect to this double movement of declaration of property and the abstention of appropriating which belongs to another.

Fichte first proceeds to determine the objective of all free action, which consists in maintaining the agent in the existence-that is to say the self-preservation and, on the other hand, making him or her the existence as enjoyable as possible. ${ }^{3}$ This ultimate end requires in turn a double operation, which is the obtaining of the raw material from nature and then manufacturing it in order to achieve the final product (Fichte, 1800: 403). For the purpose of optimizing this end, Fichte distinguishes between the class of the producers who are responsible for the first activity, and that of the artists, who are in charge of the last task. Finally Fichte introduces a third class, that of the merchants, who have the function of mediation between the raw materials and the manufactured products, which necessarily must take place between the other two classes.

Then the state must guarantee that all citizens can satisfy their basic needs, that is, they can continue to exist and carry on an enjoyable life (ein angenehmes Leben). This also means that each citizen can obtain the type of force and wellbeing which he or she needs for the own profession. ${ }^{4}$ For example, the peasant does mechanical work and therefore can live with a certain quantity of vegetables products; on the other hand, the

3 This is the ultimate end of the state which, once satisfied, opens to us the doors of the moral freedom. See Verweyen (1975: 115).

4 Even though Fichte's social division of labour aims at securing an enjoyable life for its citizens, it is not up to the citizens to determine the content of such an aim (whether it consists of mere leisure, cultivation of the spirit, sports practice, etc.). On the contrary, this is decided for the citizens by the State, which makes the Fichtean theory a form of paternalism. But this authoritarian practice would contradict the citizen's fundamental right to free action. I thank the anonymous peer-reviewer for showing me this problem. 
peasant does not need either good and clean clothes, because he or she would damage them sooner or later when cultivating. The artist, who does manual work sitting down in a room, needs a kind of nourishment that quenches the hunger a little more. The scientist in turn, who must exercise his or her mind in the imagination and invention, needs more varied nourishment and an environment that reflects the exterior purity and nobility, which must reign in his or her innermost part (Fichte, 1800: 417-418).

Nevertheless, "(...) even the farmer, on his day of rest, when he enters into a thoroughly human existence, deserves to enjoy together with the others the better things that the soil of his land grants, and wear clothing worthy of a free man." 5

Fichte expresses his ideal of an enjoyable life with the following words:

It is no mere pious wish of humanity, but the absolutely necessary [unerläßlich] demand issuing from its Right and its vocation, that it live on the earth as easily, as freely, with as much command over nature, in as truly human a way, as nature will permit. Man should labor, and yet not as a beast of burden who sinks into sleep under the weight of its load and, having just barely refreshed its exhausted forces, is roused to bear it anew. He should labor without fear, with pleasure and joy, and have time left over to raise his spirit and eye to the heavens, which he has been formed to behold. He should not simply eat together with his beast of burden, but his meals should differ as much from its feed, his dwelling from its stall, as the build of his body differs

$5 \quad$ Fichte (2012: 106). "Aber auch dem ersteren gebührt es, dass er an seinem Ruhetage, an welchem er in eine durchaus menschliche Existenz eintritt, das Bessere, welches der Boden seines Landes gewährt, mitgeniesse, und eine des freien Menschen würdige Kleidung trage" (Fichte, 1800: 418). Fichte criticizes the luxury of the nobility, because he has in mind the Rousseaunian conception of a society in which there were neither wealthy nor poor citizens but rather a robust middle class. See Batscha, (1981: 274 y 285); Braun, (1991: 37). In spite of being influenced by Rousseau, Fichte tried to overcome the error of this author, who did not apply his project to the industrialized societies of his time (Nakhimovsky, 2011: 7).

Tópicos, Revista de Filosofía 54 (2018) 
from its build. This is his right, simply because he is a human being. ${ }^{6}$

With this criterion in mind, Fichte proposes an exchange system that makes it possible to give everyone their own, not according to the hazard of the free market but rather only following which prescribes the justice. According to this system, the merchant must pay to the producer and the artist the quantity of money necessary in order to live as comfortably as possible regarding their own type of work. Then, the merchant will have to sell the good to other citizens, who in turn will have to pay the former the quantity of grain necessary to live enjoyably while he or she trades. Each of the members of this chain must receive then the quantity of grain necessary to live and exchange the remaining so as to be able to have an enjoyable life. ${ }^{7}$

\section{The necessity of a commercial state}

According to Fichte, the chance for the strangers to influence the centrally planned economy must be restrained as much as possible, because this could break the balance of the exchanges between the social classes. The reason for that consists in the fact that the stranger is not

6 Fichte (2012:110). "Es ist nicht ein blosser frommer Wunsch für die Menschheit, sondern es ist die unerlässliche Forderung ihres Rechts, und ihrer Bestimmung, dass sie so leicht, so frei, so gebietend über die Natur, so ächt menschlich auf der Erde lebe, als es die Natur nur irgend verstattet. Der Mensch soll arbeiten; aber nicht wie ein Lastthier, das unter seiner Bürde in den Schlaf sinkt, und nach der nothdürftigsten Erholung der erschöpften Kraft zum Tragen derselben Bürde wieder aufgestört wird. Er soll angstlos, mit Lust und mit Freudigkeit arbeiten, und Zeit übrig behalten, seinen Geist und sein Auge zum Himmel zu erheben, zu dessen Anblick er gebildet ist. Er soll nicht gerade mit seinem Lastthier essen; sondern seine Speise soll von desselben Futter, seine Wohnung von desselben Stalle sich ebenso unterscheiden, wie sein Körperbau von jenes Körperbaue unterschieden ist. Dies ist sein Recht, darum weil er nun einmal ein Mensch ist" (Fichte, 1800: 422-423).

7 Fichte (1800: 418-419). Jean-Christophe Merle points out that Fichte conceives the human being as a being who produces the future, the novelty in the world. The human being is respected as an end in itself when he or she can exploit his or her gifts, take care of her or his health and what Fichte calls as "to be able to live", that is to say, the subsistence, the pleasures and the free time, as means to pursue freely his or her freely posed ends. From Merle's viewpoint, that is the socialist interpretation of the categorical imperative; see Merle (1997: 204). 
subjected to the law of the state that plans its own economy and as a result cannot be controlled the way it produces and trades the goods. If each citizen were allowed to trade freely with foreigners, who in turn would do so with the dwellers of their own country, then some of them could not make a living with their work. ${ }^{8}$ The right to existence is guaranteed by the state inasmuch as each citizen promises not to exercise the craft of the others and the others promise to do so. But if in another country someone exercises a craft and trades his or her products to the citizens of other countries, then those who exercise the same craft in other countries would be prevented to trade their products. Therefore, only the state will be able to trade with other states and only when there is no alternative (Fichte, 1800: 419-421).

Fichte observes that, in modern Europe, a real war takes place where the battlefield is the trade between the countries and inside them, insofar as each one wants to maximize the profits at the lowest cost. ${ }^{9}$ That means that the highest end for all is to earn money at the expense of others, moved by greed and the uncountable needs created by the industry in constant expansion and the population in increasing rise. ${ }^{10}$ As Fichte points out, "this war will become ever more fierce and unjust and dangerous in its consequences as the world's population increases." 11

In this sense, Fichte points out the behavior of a lot of merchants who hoard goods for the purpose of increasing the prices, oftentimes preventing families from having access to necessary goods for their subsistence. Or even worse, when being forced to push down the prices,

8 Actually Carl August Struensee, in spite of his liberal ideas, stood for the limitation of the import of certain goods. See Léon (1924 : 70) (footnote).

9 For this reason, Fichte speaks about the Europe of his time as an anarchic union of states. See James (2010: 61-70); here: 66. Hume had already written in these terms in his text of 1741 entitled "On Liberty" (Nakhimovsky, 2011: 80). On the other hand, Alexandre Maurice D'Hauterive, in his State of the French Republic, had pointed out England as an imperialist power, which had been taking advantage of trade for the purpose of strenghtening its domination (Nakhimovsky, 2011: 85).

10 Fichte did not trust in the free market economy, because he considered that it resulted in a mere blind equilibrium of trade, leaving to the hazard the satisfaction of the citizen's basic needs. See Braun (1991: 34-35); Léon (1924: 98); Merle (2006: 396).

11 Fichte (2012: 145) ("dieser Krieg wird heftiger, ungerechter und in seinen Folgen gefährlicher"; Fichte, 1800: 458).

Tópicos, Revista de Filosofía 54 (2018) 
the merchants elaborate their products carelessly, lowering their quality and cheating the consumers (Fichte, 1800: 458).

Entering into the field of international commerce, Fichte considers ideal that each state exports a quantity of goods for the same value as the imported ones in order to keep a constant quantity of money in circulation and to guarantee the payment of a certain amount of money in taxes. Nevertheless, our author is aware of the fact that this only happens rarely. On the contrary, some states are usually able to produce more efficaciously the goods needed for life than others do, and as a result the others are forced to buy them. In turn, with the resultant surplus, the citizens of the state that produces better goods than the others are able to buy luxury goods and give flight to the increasing creation of artificial needs (Fichte, 1800: 460-462).

Meanwhile, from the viewpoint of the state that has been left behind, things are seen in a different way. It is an impoverished state, because it cannot produce by itself the goods their citizens need for the purpose of living, and as a result it has to buy them from another state. Consequently, its richness is constantly drained toward the state that sells the goods with the unavoidable pauperization for the state, which is in an inferior situation. Therefore, many of the citizens will emigrate from there, leaving a higher quantity of richness at the disposition of those who remain. However, this does not stop the process of deterioration of the damaged country, given that the land that is being left without inhabitants is being bought by the foreigners for profiteering. The state is forced to sell the raw materials to the richer countries, which endangers the citizens' lives themselves. Finally, the state ends up depending on the other's arbitrary decisions - sometimes for a mere subsidy (Fichte, 1800: 462-464).

The problem does not only lie in the fact that, as a result of this commercial war, some states become impoverished while others become wealthier. ${ }^{12}$ To make matters worse, other states that gain economic power are in serious danger of losing their own sovereignty, insofar as they depend for their subsistence on the fact that other states decide to buy them their products. Besides, the import of a disproportionate quantity of products could impinge against the national industry,

12 This was one of the main concerns of Carl August von Struensee, who tried to realize a monetary reform for the purpose of guaranteeing the independence of Prussia (Nakhimovsky, 2011: 105). 
because the prices of the imported goods are cheaper (Fichte, 1800: 469471).

By virtue of which has been argued hitherto, Fichte states the necessity for the states to close themselves and plan an economy that will give them independence from the commerce with other states. ${ }^{13}$ Nevertheless, the path towards the realization of this ideal is crammed with problems and difficulties. To quote some examples put by Fichte, the introduction of strong taxes for the import of goods could make a lot of citizens very angry, creating a black market, promoting smuggling and tax evasion, and forcing the introduction of an expensive control system (Fichte, 1800: 472-475).

Fichte considers it necessary to always keep in mind the distinction between the real needs, that is, those who actually contribute to wellbeing, from those based on the opinion and therefore are illusory. With Fichte's words:

We can quite well suppose that it would be hard for someone to suddenly do without Chinese tea, or have no fur coat in the winter and no light dress in the summer. Yet it is hardly clear why the coat must be of sable or the dress of silk, when the country produces neither sable nor silk. And it is even less clear why it would be so terrible if one day our clothing suddenly

13 (Fichte, 1800: 476). Unlike Fichte, Carl August Struensee was ambiguous in respect to the liberalization of the market, because on the one hand he tried to suppress the barriers for the export of grains, despite the opposition of Prussian militaries, who were afraid that the empire loses its strategic food reserves. Furthermore he stated that a public store of grains was not an appropriate measure in order to stabilize the prices in the market. On the other hand, Struensee rejected too the idea of a complete liberalization of the food market, against the French physiocrats and its German admirers. Following Arthur Young, an English specialist in agriculture, Struensee explored the possibility of subsidizing the domestic prices of the foods. In an article published in 1790, Struensee defended these protectionist measures, arguing from the starting point that the state must prioritize the subsistence of its citizens over that of the other countries (Nakhimovsky, 2011: 116-117).

Tópicos, Revista de Filosofía 54 (2018) 
lacked all that embroidery through which it is made neither warmer nor more durable. ${ }^{14}$

Despite condemning the war that the states of his time were in, he finds in some cases a rational foundation for it, inasmuch as the states want to establish their natural borders by means of war. The natural borders are those territorial extensions inside which the state can obtain the necessary resources to satisfy the citizen's basic needs. ${ }^{15}$ For this reason, Fichte considers that, once the natural borders of the state are established, the country will not have any motive to attack other communities. ${ }^{16}$ Demonstrating that it is interested only in consuming the natural borders that are allowed to take, the state is announcing its renouncement to all exterior imperialist policy (Fichte, 1800: 483-484). Consequently, the others will not have reasons to attack it (Fichte, 1800: 481-482).

Despite his declared adhesion to the Kantian project of a perpetual peace, Fichte concludes in his own project with a closed commercial

14 (Fichte, 2012: 166). "Es lässt sich sehr wohl denken, dass es einem hart falle, des chinesischen Thees plötzlich zu entbehren, oder im Winter keinen Pelz, im Sommer kein leichtes Kleid zu haben. Aber es lässt sich nicht einsehen, warum das erstere gerade ein Zobelpelz, oder das letztere von Seide seyn müsse, wenn das Land weder Zobel noch Seide hervorbringt; und noch weniger, was es für ein Unglück seyn würde, wenn an einem Tage alle Stickerei von den Kleidern verschwände, durch welche ja die Kleidung weder wärmer, noch dauerhafter wird" (Fichte, 1800: 479).

15 (Fichte, 1800: 482-483). See Philonenko (1997: 412-413). The "natural borders" of the state make possible its "self-dependence". See, Maesschalk (1996: 173). On the other hand, this concept had been alleged by France to justify its anexion of the Rhin river in 1790 (Nakhimovsky, 2011: 72).

16 Nevertheless, some interpreters see in this concept of the "natural borders" a latent danger between the states, given the ambiguity of this idea. See Batscha (1970: 192); Rametta (2004: 234); James (2010: 70). On the other hand, José Luis Villacañas argues that the Fichtean concept of the "natural borders" is dangerous, in particular because it ignores the fundamental elements of the historic development of the markets. Fichte does not take into account that the industrial production tends to accelerate and to need increasingly more resources, which would constantly push the state to extend its natural borders. On the contrary, Fichte thinks of an economic situation of an eternalized stability. See Villacañas (1999: 99). 
state. ${ }^{17}$ As David James points out, in this text, the sovereignty of each state depends exclusively on itself and not on the recognition of the other communities. On the other hand, the very idea of a federation of states loses any sense, because each state wants to minimize its relationships with the others (James, 2010: 65-66).

As Isaac Nakhimovsky states, Kant thought that the pathologies of the European States system could only be healed through the extension of the same pathology. Through the intensification of trade, war would be progressively annulled, given its opposition to the human spirit of profit and greed. On the contrary, Fichte considers that the state must act decisively and in a planned way in order to attack those pathologies, which would inevitably lead to a commercial war between the states (Nakhimovsky, 2010: 160-161).

\section{The viability of the Fichtean project}

After having hitherto developed the Fichtean project of a closed commercial state, the fundamental question of the whole project (i.e., its viability) remains unsolved. As it has been written above, Fichte's methodological standpoint consists in elaborating a theory that must balance the conceptual dimension of the foundation and the field of its empirical application. This methodological requirement demands to take into account several aspects, from the viability of the monetary system designed by Fichte, through the plausibility that a country plans its economy without seeking loans, to the sustainability of an economic policy with a very restrained exterior commerce, only to mention some relevant issues.

These issues have been already dealt with in the specialized literature. Therefore, I emphasize the problem of the need of a moral education of the citizens, as a previous step to the closure of the state. The reason for that is that the methodological requirement of the applicability of the theory demands the evaluation of the consistency between the institutional design that Fichte has in mind and the process of its realization. Thus, it is relevant to take into account the problem

17 Friedrich von Gentz states that Fichte, instead of untying the Gordian knot, nips it in the bud. The reason for that is that Fichte thinks of a state of peace between the states but without freedom, suppressing the global trade and condemning it to an eternal childhood (Nakhimovsky, 2011: 64).

Tópicos, Revista de Filosofía 54 (2018) 
of the way in which Fichte thinks that the closing of the state must be carried out. Let consider the issue in some detail.

Firstly, Fichte considers it inevitable that the state withdraws from circulation all the international common currency for the purpose of replacing them by a local one. As a consequence, citizens will not be able henceforth to trade with foreigners, which will preserve the economic balance within the community (Fichte, 1800: 484-485). Besides, the state must announce publicly the creation of the national common currency, which in turn must be made of a material, which must be adequate only to this end. In this way, the citizen's imagination will not be stimulated, avoiding the possibility that they ask for the reason why this or that material symbolizes a certain quantity of common currency. Consequently, the citizens will get quickly used to the new common currency (Fichte, 1800: 485-486).

Meanwhile, the government must guarantee the value of the common currency for all future, which in turn requires the executive power to set a permanent value for all the goods (Fichte, 1800: 487). For this reason, the state, before the enactment of the new national common currency, must buy all the foreigner goods that are still within the territory. Hence, the state will be able to increase their price, so that it will discourage the citizens who would want to buy them (Fichte, 1800: 495-496).

In this sense, in the case that any citizen must inevitably come into contact with a foreigner, he or she will have to do so through the mediation of the state, which will respond for him. For example, if a citizen owed a loan to a foreigner, the state will have to pay the latter the indebted amount of money, but it will have to do so with an international common currency (Fichte, 1800: 496-497).

Furthermore, it is the state who decides which goods must be necessarily imported, given that they cannot yet be produced in its own country. Eventually the state could lower the prices of these goods to such a degree that it will not be profitable to smuggle them (Fichte, 1800: 497-498). In a final stage, the exports must be reduced at their minimum, insofar as the project of a closed commercial state implies renouncing to transform it into a commercial power. The reason for that is that the project aims merely at the formation of an independent and autonomous nation, which guarantees the citizen's basic needs (Fichte, 1800: 499-500). 
Jean-Christophe Merle points out rightly that the Fichtean project in The Closed Commercial State differentiates from the utopias, because it is not an ideal of state to be realized in a far future but a political project to be realized immediately. Only after having closed the state will the citizens be able to modify their conceptions and behavior (Merle, 2006: 387). According to Merle's argumentation, differently from the texts of 1793 and 1794, where Fichte defended a revolution carried out by people in a contractualist way, in The Closed Commercial State, the focus is all about an autarchy imposed by use of force upon people, in an autoritarian way and without their agreement. The reason for that is that Fichte states that people must be educated a posteriori until they will be able to accept the closed commercial state, given that their prejudices in principle would lead them to reject this type of project. One of the motives for their resistance, as Merle himself points out, is that the Fichtean ideal of an enjoyable life implies the satisfaction of desires that expand into the infinite (Merle, 2006: 392-393). Therefore, even though Merle considers Fichte as a republican, inasmuch as his objective is the common distributive good, he states that Fichte violates the Kantian imperative of the publicity, insofar as the intention of the government to close the state is not revealed to the citizens (Merle, 2006: 397).

I think that even though Merle's argument reaches the right conclusion, it does not touch the core of the problem of the project of The Closed Commercial State. The reason for that is that what Merle calls "prejudices" are not mere beliefs or erroneous cognitive states but rather consist of a constellation of habits and emotional dispositions shaped by education and social interactions, which lead the citizens to have consumerist behaviors.

From my viewpoint, Fichte sees himself obliged to close the state in an authoritarian way, given that he does not have a moral psychology at his disposal, which could allow him to design an education in virtues that must be at the background of a necessary change of mentality for the purpose of abandoning the limitless search for goods and luxury. Fichte rather focuses on the institutional design of a fair state, that is, one which guarantees the right to existence to all its citizens.

This issue discloses a fundamental difference with the natural right of Jena, given that there the citizens agree to the terms of the contract of citizenship, or at least would have agreed to them in case they had been asked. This thesis is based upon the main objective of the Foundations of Natural Right, which consists of the protection of the conditions of 
realization of self-consciousness (Fichte, 1796/1797: 17). In order for this to be possible, the I must be able to establish a relationship of mutual recognition, which implies the mutual respect for his or her spheres of free action (Fichte, 1796/1797: 34 ss. y 52). In turn, this task can be performed only by the state, because it is a third instance that is not involved in the disputes of the citizens about their property (Fichte, 1796/1797: 157).

Therefore, the subjects, as rational beings, inevitably will want to enter into the civil state, and no manipulation will be necessary to do so. Even more, the process of the constitution of the state consists of a series of contracts that progressively solidify the realization of the common will. In other words, in the Foundations of Natural Right all the political, legal and economic structure is based upon an explicit agreement of the citizens. This agreement is possible because it is assumed that all the citizens want to protect the conditions of their self-consciousness. But it is reinforced by the assumption of the universal egoism as well, which leads the citizens to fulfill the law out of self-interest.

From the viewpoint of the development of the Fichtean political thought, The Closed Commercial State presents an additional problem with respect to the natural right of Jena, inasmuch as it introduces a higher complexity in the idea of the ultimate end of the state. In the natural right, this consists in the guarantee that each citizen will be able to make a living through his or her work. Given this ultimate end, the assumption of the rational egoism is consistent with the prudential calculation of the citizens, who prioritize the conservation of their own life.

In my opinion, the rational egoism is not able to give applicability to the theory of natural right, given that it implies the transference of all the power to the government without possibility of participation of the citizenship, except for the case that the government is brought to a political trial. As it was written before, this carries bigger problems in the field of the international right, inasmuch as it leaves the possibility of the declaration of a war in a latent state and puts peace in the hands of a precarious equilibrium of power between the states.

According to which has been written before, Fichte undertakes again the search for a solution to the problem of the establishment of peaceful relationships between the states. Thereto, Fichte tries to rectify in The Closed Commercial State a defect that has his natural right of Jena, which resides in the fact that he does not give account of the distribution 
of the property between the states and of the relationships of conflict, dependency, and domination that it generates. Meanwhile, in order to protect the economic sovereignty of the state, it is necessary to close trade as much as possible.

This requires that the citizens restrain their consumption, limiting their needs to the extent of which the natural borders of the community are able to offer. But in this point, Fichte faces an additional challenge, given that it has been added to the ultimate end of providing the selfpreservation of the citizens in the existence: the component of having an enjoyable life. This ideal is more demanding and robust than that defended in the natural right of Jena, inasmuch as it implies the enjoyment of certain pleasures as well as the cultivation of the imagination and the higher faculties of the spirit.

As a result, the enjoyment of free time for leisure becomes a central condition for the achievement of the highest ideal of state. But, as David James argues, it can happen that, despite having enough free time, the citizens do not take advantage of it for their own improvement and moral progress, because the work has stupefied them too greatly. Hence, it would be desirable that the Fichtean project came coupled with a series of formative instances in an integral sense and not merely with a scheme for a social division of labour (James, 2015: 509-528).

To demonstrate that the citizens are capable of sustaining an institutional design of this kind, it is necessary to appeal to a moral psychology that is more complex than the mere assumption of the rational egoism, insofar as here we are not dealing with a strategic calculation of the minimum conditions to survive. My conclusion is that, with the finality of having an enjoyable life in mind, the citizens should be capable of developing a series of virtues or dispositions to act; this would allow them to refrain from or shape the greed for goods, which according to Fichte is the inevitable product of the development of the industry and the modernization of our societies. ${ }^{18}$

In this paper, I consider that the Fichtean project of a closed commercial state has a limit, which is given by the lack of an educative policy in an integral sense but in particular in certain virtues that promote

18 Nevertheless, it remains open whether or not the problem of the Fichtean theory would allow for a moral education of the citizens, given that it is meant as a theory completely independent of ethics. I thank the anonymous peer-reviewer for this suggestion.

Tópicos, Revista de Filosofía 54 (2018) 
alternative values in respect to the compulsive consumerism. In other words, I think that it is not possible to think of a change of economic and social structures without previously promoting a development of the subjectivity, which must lay the grounds in order to give sustainability to the planned transformations.

\section{Bibliography}

Batscha, Z. (1981). Studien zur politischen Theorie des deutschen Frühliberalismus. Frankfurt am Main: Suhrkamp Verlag.

(1970). Gesellschaft und Staat in der politischen Philosophie Fichtes. Frankfurt am Main: Europäische Verlagsanstalt.

Braun, J. (1991). Freiheit, Gleichheit, Eigentum. Grundfragen des Rechts im Lichte der Philosophie J.G. Fichtes. Tübingen: J.C.B. Mohr (Paul Siebeck).

Fichte, J. G. (2012). The Closed Commercial State. A. C. Adler. (trans.) New York: State University of New York.

(1800). Der Geschlossene Handelstaat. Reprinted in: Fichte, I. H. (ed.) (1971). Johann Gottlieb Fichte: Sämmtliche Werke. Berlin: Walter de Gruyter, Volume III.

(1796/1797). Grundlage des Naturrechts nach der Principien der Wissenschaftslehre. Reprinted in: Fichte, I. H. (ed.) (1971). Johann Gottlieb Fichte: Sämmtliche Werke. Berlin: Walter de Gruyter, Volume III.

James, D. (2015). Conceptual Innovation in Fichte's Theory of Property: The Genesis of Leisure as an Object of Distributive Justice. European Journal of Philosophy, 23/3, 509-528.

(2010). Fichte's Reappraisal of Kant's Theory of Cosmopolitan Right. History of European Ideas, 36, 61-70.

Kant, I. (1795). Zum ewigen Frieden. Ein philosophischer Entwurf, en: Kants Gesammelte Schriften, herausgegeben von der Preussischen Akademie der Wissenschaften. Berlin. (1902 ss.). The text is quoted with volume and page number.

Léon, X. (1924). Fichte et son temps. II. Fichte à Berlin (1799/1813). Première Partie. Lutte contre l'esprit de réaction (1799/1806). Paris: Librairie Armand Colin.

Lindau, H. (1900). Johann Gottlieb Fichte und der neuere Sozialismus. Berlin W. F. Fontane \& Co. Nachdruck. En: Lindau, H. \& Weber, M. (1987). 
Schriften zu J.G. Fichtes Sozialphilosophie. Mit Personenregistern von Hans Michael Baumgartner. Hildesheim - Zürich - New York.

Maesschalk, M. (1996). Droit et creation sociale chez Fichte. Une philosophie moderne de l'action politique. Louvain-Paris, Éditions de L'Institut Supérieur de Philosophie Louvain-La- Neuve: Éditions Peeters.

Marquardt, J. (1991). Der geschlossene Handelstaat. Deutsche Zeitschrift für Philosophie, 3/1991, 294-303.

Merle, J.-Ch. (2006). Johann Gottlieb Fichte, Der geschlossne Handelstaat (1800). En: Geschichte des politischen Denkens. Brocker, M. (ed.) (387402). Frankfurt am Main: Suhrkamp.

(1997). Justice et progrès. Paris: Presses Universitaires de France.

Moggach, D. (2009). Freedom and Perfection: German Debates on the State in the Eighteen Century. En: Canadian Journal of Political Science / Revue canadienne de science politique, 42:4, 1003-1023.

Nakhimovsky, I. (2011). The Closed Commercial State. Perpetual Peace and Commercial Society from Rousseau to Fichte. Princeton and Oxford: Princeton University Press.

Philonenko, A. (1997). Métaphysique et politique chez Kant et Fichte. Paris: Libraire Philosophique Vrin.

Rametta, G. (2004). Politik der Vernunft und Vernunftstaat bei Fichte (1793-1808). En Fichte und die Aufklärung. De Pascale, Carla, Fuchs, Eric, Ivaldo, Marco, Zöller, Günther, (hrsg.) (227-241). HildesheimZürich-New York: Georg Olms Verlag.

Verweyen, H. (1975). Recht und Sittlichkeit in J. G. Fichtes Gesellschaftslehre. München: Verlag Karl Alber Freiburg.

Villacañas. J. L. (1999). La nación y la guerra. Confederación y hegemonía como formas de concebir la guerra. Murcia: Diego Marín Librero Editor. Weber, M. (1900). Fichte's Sozialismus und sein Verhältnis zur Marx'schen Doktrin, Tübingen Freiburg i.B. und Leipzig: Verlag von J.C.B. Mohr (Paul Siebeck). Reimpreso en: Lindau, H. \& Weber, M. (1987). Schriften zu J.G. Fichtes Sozialphilosophie. Mit Personenregistern von Hans Michael Baumgartner. Hildesheim - Zürich - New York. 